\title{
Suitability of Some Nigerian Barites in Drilling Fluid Formulations
}

\section{Ugochukwu Ilozurike Duru*, Anthony Kerunwa, Ifeanyi Omeokwe, Nnaemeka Uwaezuoke, Boniface Obah}

Department of Petroleum Engineering, Federal University of Technology, Owerri, Nigeria

Email address:

ugochukwu.duru@futo.edu.ng (U. I. Duru)

${ }^{*}$ Corresponding author

\section{To cite this article:}

Ugochukwu Ilozurike Duru, Anthony Kerunwa, Ifeanyi Omeokwe, Nnaemeka Uwaezuoke, Boniface Obah. Suitability of Some Nigerian Barites in Drilling Fluid Formulations. Petroleum Science and Engineering. Vol. 3, No. 2, 2019, pp. 46-59. doi: 10.11648/j.pse.20190302.13

Received: September 10, 2019; Accepted: October 11, 2019; Published: October 24, 2019

\begin{abstract}
In order to counter-balance the formation pressure, the drilling mud is weighted up using a chemical additive, usually Barite. The usability of locally sourced Nigerian Barites on the major types of drilling fluids in conventional conditions is presented. Water-Based mud, Oil-Based mud and Synthetic-Based mud formulations with locally sourced Barite were tested according to the American Petroleum Institute recommended practices. Hole cleaning capabilities of the formulations by the use of Cutting Carrying Index (CCI) and Cutting Concentration (CC) as indicators showed that Osina, Gabu and Obubra Nigerian Barites are suitable for use as drilling fluid additives; with Cutting Carrying Index in the range of 23.27 to 120.54 for Water-Based mud, 0.89 to 3.98 for Oil-Based mud and 0.45 to 1.13 for Synthetic-Based mud. The Cutting Concentration of average of 4.15 vol. $\%$ at $355 \mathrm{gpm}$ and $300 \mathrm{ft} / \mathrm{hr}$ ROP for Water-Based mud, Oil-Based mud and Synthetic-Based mud, with MAXROP of $364 \mathrm{ft} / \mathrm{hr}$ under the same conditions was recorded. Moreso, laminar flow regime in the annulus was predicted for all the mud types under the same conditions and temperatures specified, based on a MATLAB programme developed to perform the computation. Cutting Carrying Index for water based mud decreased from ambient, $120^{\circ} \mathrm{F}, 180^{\circ} \mathrm{F}$ to $240^{\circ} \mathrm{F}$ compared with API mud used as control sample.
\end{abstract}

Keywords: Cutting Carrying Index, Cutting Concentration, Barite, High-Pressure-High-Temperature, Mud Formulations

\section{Introduction}

Nigeria is one of the highest crude oil exporting countries in the world and therefore has various ongoing exploration and production activities. In order to produce crude oil, wells are drilled into the formation either as exploratory, production or appraisal wells. These wells must be drilled to satisfy three basic conditions;

i. It must be safe.

ii. It must be usable.

iii. It must be economical.

Borehole stability is very crucial and requires constant monitoring throughout a drilling operation. A borehole is said to be stable when the formation pressure is less than or equal to the hydrostatic pressure. Drilling operations conventionally operate on an overbalance where the hydrostatic pressure is maintained slightly above the formation pressure. Where the hydrostatic pressure is lower than the formation pressure, the borehole is exposed to well problems such as sloughing, kick or blowout. Drilling a hole involves penetrating through several strata of formation and requires special technique to economically and safely reach the target depth.

Drilling fluids are generally the "blood" of all drilling operations and the petroleum industry especially. The industry has continued to make increasing use of these fluids, the cost of which can account for over $20 \%$ of total operating costs. To minimise the cost as well as improve performance and safety, other generic types of these fluids are continuously being developed mainly to meet the increasing challenges [1]. They include;

i. Deeper well drilling/completion especially in high temperature and pressure environment.

ii. Increasing use of advanced wells (ERD, multilateral and horizontal wells). 
iii. Stiff environmental regulations.

This study aims to determine the usability of Nigerian barite as an additive in different types of drilling fluids that can be used especially in high temperature and high pressure environments as compared to imported barite. This laboratory investigation covers rheological and filtration properties of formulated water, oil, and synthetic based drilling fluids using Nigerian barites as weighting material. In this study, the chemical analysis of the Nigerian barites and Irvingia gabonensis oil was not considered but its specific gravity and flash point respectively were determined.

\section{Literature Review}

Local materials sourced from Nigeria have shown satisfactory performances in mud formulations as viscosifiers, fluid loss control agents and weighting materials. Also, the materials showed improved borehole cleaning capabilities of drilling muds.

Higher yield stress for a mud formulation from Irvingia gabonensis when compared with a conventional mud has been reported [2]. The conventional mud was used as a control test, while different combinations of local materials were prepared, tested and the results compared with the conventional mud. In the work, it was highlighted that the biopolymer exhibited good transport ratio, an indicator for good wellbore cleaning capability of muds. The author concluded that the mud formulation would be most suitable for shallow wells because of the temperature range on which the experiments were carried out. Though the author in this work did not show the value of the yield of Irvingia gabonensis, but suggested the need to refine the biopolymer in order to have equal measure with the conventional polymer, and its suitability in high temperature high pressure drilling.

Cassava starch was used as an additive to improve the rheological properties of water based muds by altering its concentration [3]. The authors discovered that cassava starch improves the rheological properties of water based muds and suggested an optimum composition of $4 \%$ starch in a drilling mud.

An aqueous based mud formulation from biopolymers and effects of temperature on the mud formulation has also been presented [4]. Properties such as fluid loss, yield point and plastic viscosity were shown to be temperature dependent properties.

Also, the use of $3 \mathrm{rpm}$ reading viscometer, for Power Law fluids, as the yield point of drilling fluids, since Bingham plastic model over-predicts the yield point has been recommended [5].

\section{Weighting Materials}

The choice of weighting agents to be used in drilling fluids is usually determined by many factors. One of the most important factors is to provide low rheology in high density fluids and low sag [6].

There are specialized weighting agents such as Manganese Tetraoxide $\left(\mathrm{Mn}_{3} \mathrm{O}_{4}\right)$ or treated micronized Barium Sulphate with an average particle size of 1 micron. These can provide high density fluids with low sag, low rheology and are less damaging to the formation. $\mathrm{Mn}_{3} \mathrm{O}_{4}$ is used in both drilling and completion fluids when low sag, low rheology and low ECD management is required [7].

Limonite was first introduced into the industry with a particle size of 30-45 microns as a weighting material in 1976 [8]. However its use was limited because of its abrasiveness to drilling equipment.

Results from experiments have also shown that ilmenite has a sag factor of $<0.3$ and a PV range of $25-30 \mathrm{cp}$ which is lower than barite. HTHP filtration tests under static conditions showed filter cake had a thickness of 0.18 in and $2.9 \mathrm{~cm}^{3}$ of filtrate volume, while under dynamic condition, filter cake thickness was 0.15 in and filter cake volume 2.2 $\mathrm{cm}^{3}$. Micronized ilmenites require less viscosifiers to be well dispersed, needs slightly more dispersant and wetting agents when compared to API Barite.

An attempt to substitute "tiro" (modified antimony sulphide also known as stibnite) for barite as a weighting material has been reported [9]. On comparison, the authors discovered that barite gave a better weighting strength than "tiro" and barite also had less effect on the $\mathrm{pH}$ but "tiro" was more favourable in terms of mud viscosity.

Field and laboratory evaluation on the use of ilmenite as a weighting material have also been carried out [10]. It was observed that there was a flow induced abrasion when ilmenite is used in drilling fluids and they sort to laboratory for confirmation. They discovered the abrasiveness was due to particle size distribution and recommended a distribution of $<3 \%$ particles greater than 45 microns. The authors also discovered other problems related to the use of ilmenite such as dust, dispersion of ilmenite in water, air entrainment and foaming. They recommended a reduction in concentration of floatation chemicals as a remedy. They stated that ilmenite was more expensive than barite but its cost was expected to decrease in future.

The density of a drilling fluid must be controlled to provide adequate hydrostatic head to prevent influx of formation fluid into the wellbore and also to achieve wellbore stability. The hydrostatic head should not be too high to avoid drilling problems such as lost circulation, poor drilling rate or even fracture the formation. The drilling window profile of the formation should be taken into consideration before choosing the hydrostatic pressure to operate on.

The density of any fluid is directly related to the amount and average specific gravity of solids in the fluid. The control of density is critical since the hydrostatic pressure exerted by the column of fluid is required to contain formation pressure and aid in keeping the borehole open. The density of a drilling fluid should be dictated by the formation pressure encountered. Density could be measured in pounds per gallon (ppg) or pounds per cubic feet $\left(\mathrm{lb} / \mathrm{ft}^{3}\right)$.

Conventional drilling involves maintaining the hydrostatic pressure slightly above the formation pressure. As drilling goes deeper the formation, the formation pressure exerted on 
the well increases; hence a higher hydrostatic pressure is required for well control. This is done by increasing the mud weight of the drilling fluid by addition of weighting materials. Barite, an additive used as a weighting material in the formulation of almost all types of drilling fluids is being imported into the country, whereas Nigeria is blessed with this mineral in commercial quantities. The mineral is left untapped or under-produced due to very low demand. In a country where drilling operations are carried out daily, it is beneficial to its economy that the materials used in carrying out these activities are sourced locally. This would enable easy and cheaper procurement of materials for operating companies, create employment opportunities for the locals and encourage local content which the Government of Nigeria has been advocating for through the Nigerian
Content Development and Monitoring Board (NCDMB).

Barite is a crystalline heavy material chemically composed basically of Barium Sulphate (BaSO4), usually 58.8\% Barium. It is usually associated with impurities like Silicon (IV) oxide or Lead Sulphides. It is a heavy mineral compound that occurs naturally as large veins or beds. Barites can occur as gangue minerals in various mineral veins, in limestones, sandstones and like deposits [11]. Barite is chemically inert and insoluble in water or oil.

About $80 \%$ of barite in the world is used as a weighting material in drilling fluids in oil and gas exploration to suppress high formation pressures and prevent blow out [12]. It is also used in the paint and pharmaceutical industries. Other alternatives have been explored in recent times [13].

\section{World barite production \& consumption 2015}

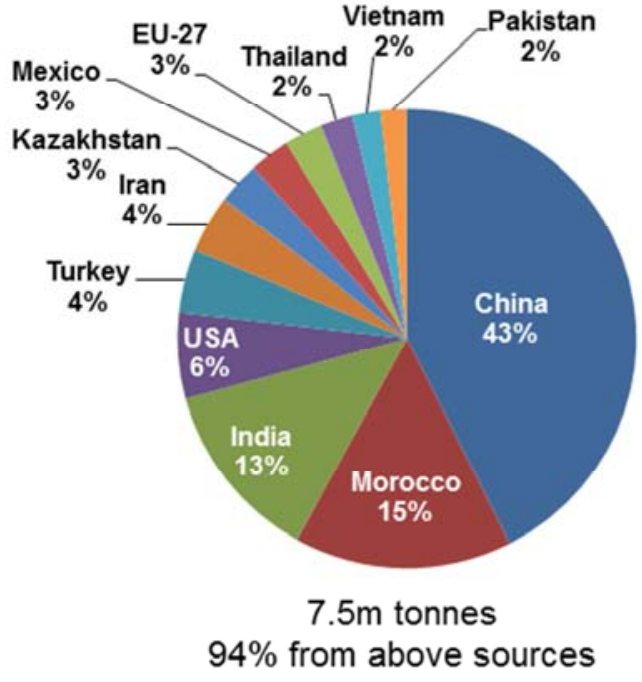

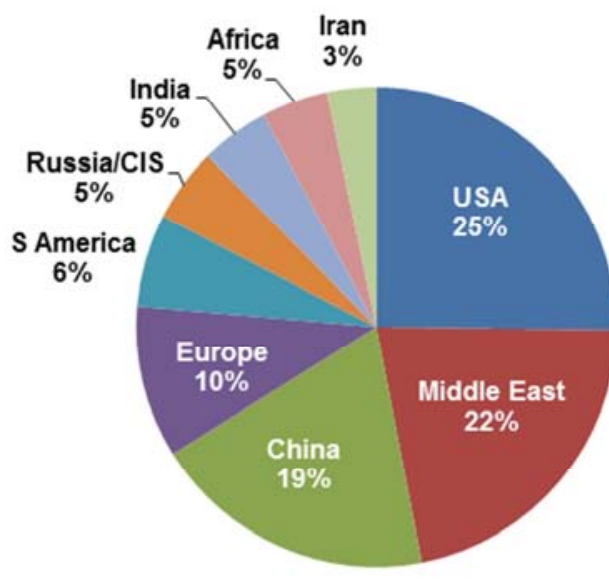

$8 m$ tonnes

$93 \%$ consumed in above regions

(Nigeria imported 17,406t in 2015)

Source: The Barytes Association; $\pi \mathrm{C}$ data

ब) GMFORMED 2017 | imformed.com

Figure 1. World Barite Production and Consumption [12].

Figure 1 shows world's barite production. Nigeria is blessed with many solid minerals, and Barite is one of those minerals found in commercial quantity. Barites in Nigeria occur as vein infilling materials, commonly associated with lead-zinc lodes and veins in both pre-Cambrian basement and Cretaceous sedimentary rocks of the lower and middle Benue valley. The mineral occurs mostly in white, reddish-brown and clear varieties with specific gravity varying in the range of 3.5-4.4. The width of veins ranges from a few centimetres to 5.3meters. Length of veins also vary from few metres to $>4500 \mathrm{~m}$ [11]. Preliminary survey carried out by the Geological Survey of Nigeria in 1959 put the estimated reserve at 41,000tonnes for the Benue valley deposits. Also the Nigerian Mining Corporation estimated the resource at 70,000 tonnes in the Azarra deposit in Nassarawa State. Recently, the Nigerian Geological Survey Agency embarked on the evaluation of newly reported deposits in Cross River, Benue, Nassarawa, Plateau, and Taraba States. The inferred resource estimated for four states where mining is considered viable is $21,123,913$ metric tonnes [11].

\section{Materials and Method}

Five (5) samples of each type of mud (WBM, OBM and SBM) were formulated with identical compositions; unweighted and then weighted with the barite samples. The rheological properties of 15 samples of weighted mud were analysed and compared to determine the effect of the varied weighting material in each mud sample.

\subsection{Barite Samples}

Figure 2 shows unprocessed barite samples. The barite 
samples used were obtained from different Barite deposit locations in Nigeria. The samples were labelled $\mathrm{B}_{1}-\mathrm{B}_{4}$, and sample $\mathrm{B}_{0}$ is the imported barite sample.

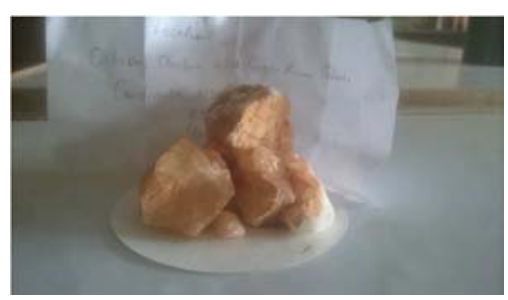

Figure 2. Unprocessed Barite sample.

\subsubsection{Preparation of Barite}

The samples obtained from the Barite Veins were still in rock form and are required to be micronized to be used in the laboratory. The procedure used in barite sample preparation is presented;

A. Apparatus: Grinder, sieves, wire brush, measuring cylinder, petri-dish, weighing balance.

B. Materials: Barite rock, fresh water.

Procedure:

1. Each Barite Rock Sample was cleaned with water and wire brush in order to remove the external impurities for instance Silicon (IV) Oxide and Quartz.

2. The cleaned sample was dried in the laboratory at room temperature to prevent dust and other impurities from settling on it.

3. The dried barite samples were pulverised using a mortar and pestle.

4. A sieve was used to ensure the particles size was relatively homogenous (average particle size $<25 \mu \mathrm{m}$ ).

Table 1. API specification for Barite.

\begin{tabular}{ll}
\hline Specific gravity & $4.2(\min )$ \\
Soluble metals or calcium: & $250 \mathrm{ppm}(\max )$ \\
Wet Screen Analysis & \\
Residue on No. 200 sieve: & $3 \%(\max )$ \\
Residue on No. 325 sieve: & $5 \%(\min )$ \\
\hline
\end{tabular}

Specific Gravity of a liquid or solid substance is the relative density of that substance to the density of water. From the Table 1, Specific Gravity specification is shown. The specific gravity of barite is the defining property that directly affects the mud weight. Due to the limiting resource of 4.2 SG barite worldwide, API has approved of a $4.1 \mathrm{SG}$ barite for use [14].

\subsubsection{Specific Gravity of the Barite Samples}

The measuring cylinder method of obtaining the specific gravity of solids was employed.

A. Apparatus: Measuring cylinder, weigh balance.

B. Materials: Micronized Barite, fresh water.

Procedure:

1. A measuring cylinder was washed, dried, cleaned and weighed empty, the mass of the measuring cylinder was recorded, $\mathrm{m}_{1}$.

2. Fresh water was poured into the measuring cylinder and weighed, the mass was recorded, $\mathrm{m}_{2}$.

3. The volume of the water was recorded, $\mathrm{v}_{1}$.

4. A mass of barite sample was weighed and recorded, $\mathrm{m}_{\mathrm{b}}$.

5. The weighed barite was poured into the measuring cylinder containing water, weighed and recorded $\mathrm{m}_{3}$.

6 . The volume of water and barite was recorded, $v_{2}$.

7. The difference between the $m_{2}$ and $m_{1}$ gives the mass of water, $\mathrm{m}_{\mathrm{w}},\left(\mathrm{m}_{2}-\mathrm{m}_{1}=\mathrm{m}_{\mathrm{w}}\right)$

8. The difference between $v_{2}$ and $v_{1}$ gave the equivalent volume of the mass of barite, $v_{b},\left(v_{2}-v_{1}=v_{b}\right)$

$$
\begin{gathered}
\text { Specific Gravity }=\frac{\text { density of substance }}{\text { density of water }} \\
\text { Density of Substance }=\frac{\operatorname{mass}(\mathrm{g})}{\operatorname{volume}\left(\mathrm{cm}^{3}\right)}
\end{gathered}
$$

Equations (1) and (2) are fundamental equations in material balance calculations.

\subsection{Mud Formulation}

A pilot test was carried out in the laboratory in order to predict the behaviour of the drilling fluid in well conditions. The generic components of the basic drilling fluid types were used in the formulation of the drilling fluids. All the mud samples used in this investigation were formulated and tested following the API Recommended Practices [15].

The mud formulation involves mixing several substances to achieve a desired specification of drilling fluid. The components used in making the drilling fluid can be grouped thus; base fluid, viscosifiers, fluid loss control additives, and $\mathrm{pH}$ control additives. The components were mixed in specific ratios and based on the mud design desired. Equipment used in the formulation of the drilling fluid include Hamilton Beach mixer, measuring cylinder, weighing balance - used for weighing chemicals, and spatula.

\subsubsection{Water Based Mud}

Water based mud is usually used as spud mud or in shallow wells and thus requires less additives. Table 2 shows its compositions;

Table 2. Composition of Water-based mud.

\begin{tabular}{llllll}
\hline Components & $\mathbf{B}_{\mathbf{0}}$ & $\mathbf{B}_{\mathbf{1}}$ & $\mathbf{B}_{\mathbf{2}}$ & $\mathbf{B}_{\mathbf{3}}$ & $\mathbf{B}_{\mathbf{4}}$ \\
\hline Water & $350 \mathrm{ml}$ & $350 \mathrm{ml}$ & $350 \mathrm{ml}$ & $350 \mathrm{ml}$ & $350 \mathrm{ml}$ \\
Bentonite & $21 \mathrm{~g}$ & $21 \mathrm{~g}$ & $21 \mathrm{~g}$ & $21 \mathrm{~g}$ & $21 \mathrm{~g}$ \\
Caustic Soda & $0.4 \mathrm{~g}$ & $0.4 \mathrm{~g}$ & $0.4 \mathrm{~g}$ & $0.4 \mathrm{~g}$ & $0.4 \mathrm{~g}$ \\
Soda ash & $0.4 \mathrm{~g}$ & $0.4 \mathrm{~g}$ & $0.4 \mathrm{~g}$ & $0.4 \mathrm{~g}$ & $0.4 \mathrm{~g}$ \\
PAC R & $0.3 \mathrm{~g}$ & $0.3 \mathrm{~g}$ & $0.3 \mathrm{~g}$ & $0.3 \mathrm{~g}$ & $0.3 \mathrm{~g}$ \\
Unweighted Mud & $8.6 \mathrm{ppg}$ & $8.6 \mathrm{ppg}$ & $8.6 \mathrm{ppg}$ & $8.6 \mathrm{ppg}$ & $8.6 \mathrm{ppg}$ \\
weight & $70 \mathrm{~g}$ & $70 \mathrm{~g}$ & $70 \mathrm{~g}$ & $70 \mathrm{~g}$ & $70 \mathrm{~g}^{+}$ \\
Barite & $9.3 \mathrm{ppg}$ & $9.5 \mathrm{ppg}$ & $9.3 \mathrm{ppg}$ & $9.4 \mathrm{ppg}$ & $9.4 \mathrm{ppg}^{+}$ \\
Weighted Mud weight & & & & &
\end{tabular}

\subsubsection{Oil Based Mud}

The preparation process of the oil based mud is quite similar to that of the water based mud. The continuous phase is made up of oil and water mixture. In this experiment, 
diesel oil was mixed with water in the ratio of 80:20. API

Table 3 gives the composition of oil based mud.

Recommended Procedures were observed in this study. The

Table 3. Composition of (Diesel) Oil based mud.

\begin{tabular}{llllll}
\hline Components & $\mathbf{B}_{\mathbf{0}}$ & $\mathbf{B}_{\mathbf{1}}$ & $\mathbf{B}_{\mathbf{2}}$ & $\mathbf{B}_{3}$ & $\mathbf{B}_{4}$ \\
\hline Diesel & $270 \mathrm{ml}$ & $270 \mathrm{ml}$ & $270 \mathrm{ml}$ & $270 \mathrm{ml}$ & $270 \mathrm{ml}$ \\
Water & $67 \mathrm{ml}$ & $67 \mathrm{ml}$ & $67 \mathrm{ml}$ & $67 \mathrm{ml}$ & $67 \mathrm{ml}$ \\
Bentonite & $21 \mathrm{~g}$ & $21 \mathrm{~g}$ & $21 \mathrm{~g}$ & $21 \mathrm{~g}$ & $21 \mathrm{~g}$ \\
Primary Emulsifier & $7 \mathrm{ml}$ & $7 \mathrm{ml}$ & $7 \mathrm{ml}$ & $7 \mathrm{ml}$ & $7 \mathrm{ml}$ \\
Caustic Soda & $0.4 \mathrm{~g}$ & $0.4 \mathrm{~g}$ & $0.4 \mathrm{~g}$ & $0.4 \mathrm{~g}$ & $0.4 \mathrm{~g}$ \\
Soda ash & $0.4 \mathrm{~g}$ & $0.4 \mathrm{~g}$ & $0.4 \mathrm{~g}$ & $0.4 \mathrm{~g}$ & $0.4 \mathrm{~g}$ \\
PAC R & $0.2 \mathrm{~g}$ & $0.2 \mathrm{~g}$ & $0.2 \mathrm{~g}$ & $0.2 \mathrm{~g}$ & $0.2 \mathrm{~g}$ \\
Unweighted Mud weight & $7.8 \mathrm{ppg}$ & $7.8 \mathrm{ppg}$ & $7.8 \mathrm{ppg}$ & $7.8 \mathrm{ppg}$ & $7.8 \mathrm{ppg}$ \\
Barite & $70 \mathrm{~g}$ & $70 \mathrm{~g}$ & $70 \mathrm{~g}$ & $70 \mathrm{~g}$ & $70 \mathrm{~g}$ \\
Weighted Mud weight & $9.0 \mathrm{ppg}$ & $9.3 \mathrm{ppg}$ & $9.0 \mathrm{ppg}$ & $9.2 \mathrm{ppg}$ & $9.2 \mathrm{ppg}$ \\
\hline
\end{tabular}

\subsubsection{Synthetic Mud}

The preparation process of the synthetic based mud is similar to that of the oil based mud. The base fluid is an Olefin isomer that is non toxic and biodegradable. Due to characteristics of this base fluid, certain additives such as the bridging agent and emulsifier were imperative. The continuous phase was made up of a synthetic oil and water mixture. In this experiment, synthetic oil was mixed with water in a ratio of 75:25. Table 4 describes the formulation used in this work. API Recommended Procedures were observed.

Table 4. Composition of Synthetic mud.

\begin{tabular}{|c|c|c|c|c|c|}
\hline Components & $\mathbf{B}_{0}$ & $\mathbf{B}_{1}$ & $\mathbf{B}_{2}$ & $\mathbf{B}_{3}$ & $\mathbf{B}_{4}$ \\
\hline Base fluid & $207 \mathrm{ml}$ & $207 \mathrm{ml}$ & $207 \mathrm{ml}$ & $207 \mathrm{ml}$ & $207 \mathrm{ml}$ \\
\hline Organophilic clay & $8 g$ & $8 g$ & $8 g$ & $8 g$ & $8 g$ \\
\hline Lime & $8 g$ & $8 g$ & $8 g$ & $8 \mathrm{~g}$ & $8 \mathrm{~g}$ \\
\hline Primary Emulsifier & $6 \mathrm{ml}$ & $6 \mathrm{ml}$ & $6 \mathrm{ml}$ & $6 \mathrm{ml}$ & $6 \mathrm{ml}$ \\
\hline Water & $68 \mathrm{ml}$ & $68 \mathrm{ml}$ & $68 \mathrm{ml}$ & $68 \mathrm{ml}$ & $68 \mathrm{ml}$ \\
\hline Calcium Chloride & $32 \mathrm{~g}$ & $32 \mathrm{~g}$ & $32 \mathrm{~g}$ & $32 \mathrm{~g}$ & $32 \mathrm{~g}$ \\
\hline Fluid Loss Agent & $2 g$ & $2 g$ & $2 g$ & $2 \mathrm{~g}$ & $2 \mathrm{~g}$ \\
\hline Barite & $70 \mathrm{~g}$ & $70 \mathrm{~g}$ & $70 \mathrm{~g}$ & $70 \mathrm{~g}$ & $70 \mathrm{~g}$ \\
\hline Weighted Mud weight & $10.5 \mathrm{ppg}$ & $10.7 \mathrm{ppg}$ & $10.5 \mathrm{ppg}$ & 10.6ppg & $10.7 \mathrm{ppg}$ \\
\hline
\end{tabular}

\subsection{Mud Weight}

The mud weight was measured using a mud balance. The mud balance consists of a constant volume cup with a lever arm and a rider calibrated to read directly the density of a fluid in ppg. The arm rests on a fulcrum and with the help of a level vial; an accurate balance can be obtained.

\subsection{Rheology Tests}

Materials: Freshly prepared drilling mud samples, masking tape, recording book and pen.

The objective of rheology tests is to measure the viscosity and gel strength that relate to the flow properties of the mud. It has already been established in the literature that the presence of solid in the drilling fluid has a role to play in the viscosity and gel strength of the fluid.

The rheology test was conducted by the use of eight rotational speeds $(600,300,200,100,60,30,6$, and $3 \mathrm{rpm})$ OFITE 800 viscometer. It is used to directly measure the viscosity of the drilling fluid. The shear stress (scale reading) was determined as a function of the shear rate (from the rotational speed). In this study, the test procedures followed the recommended practice of standard procedure for field testing drilling fluid [15]. The plastic and apparent viscosities were obtained using the basic mathematical relationships given as Equations (3) and (4), while yield point presented as indicated with Equation (5);

$$
\text { Plastic Viscosity }(\mathrm{PV})=600 \text { reading }-300 \text { reading }
$$

$$
\text { Apparent Viscosity }(A V)=\frac{P V}{2}
$$

$$
\text { Yield Point }(\mathrm{YP})=3 \text { dial reading }
$$

The carrying capacity index CCI was calculated using parameters derived from the viscometer readings. The carrying capacity index can give us more information about the hole cleaning capability of the drilling fluid. If the $\mathrm{CCI}$ is equal to or less than 0.5 , then the hole cleaning is poor. Where the CCI is equal to or greater than 1.0 , then it indicates that hole cleaning is very good. The fluid flow index (n), also gives information about the rheology of the fluid. Where $\mathrm{n}$ is less than 1 , the fluid is said to be shear thinning (pseudoplastic), where $\mathrm{n}$ is equal to 1 , the fluid is a Newtonian fluid and where $\mathrm{n}$ is greater than 1 , the fluid is 
said to be shear thickening (dilatant).

It is a rule of thumb in any drilling fluid operation that the advisable minimum and maximum flow rates for an 8.5 inch well is $355 \mathrm{gpm}$ and $510 \mathrm{gpm}$ respectively [16]. Hence, the range of minimum and maximum annular velocity is between $214 \mathrm{ft} / \mathrm{min}$ and $308.4 \mathrm{ft} / \mathrm{min}$. In this work, the following assumptions were made.

i. Hole diameter $\left(\mathrm{d}_{\mathrm{h}}\right)=8.5$ in

ii. Drill pipe OD $\left(\mathrm{d}_{\mathrm{p}}\right)=5.5$ in

iii. Annular velocity $(\mathrm{AV})=270 \mathrm{ft} / \mathrm{min}$

\subsection{Gel Strength}

The OFITE 800 Model Viscometer was also used to obtain the gel strength of the mud. The mud was stirred at $600 \mathrm{rpm}$ and then allowed to settle for 10 seconds before turning the dial to gel to get the 10 s gel strength. Same procedure was taken for the 10 minutes gel strength but settling time was 10 minutes.

\subsection{Fluid Loss Tests}

The fluid loss properties of the drilling fluid samples were carried out at high temperature and high pressure conditions. An OFITE 900 HTHP filter press was used to measure the filtration properties of the drilling fluids at high temperature and pressure of $250^{\circ} \mathrm{F}$ and 300 psi. API Recommended Procedures was observed while carrying out this test.

\section{Results Presentation}

\section{Results and Discussion}

Drilling fluid samples were tested and analyzed to determine the composition, physical and rheological properties, and fluid loss properties of drilling fluid samples tested and analysed are reported in this section.

Specific Gravity of Barite

The quality of barite is measured based on its specific gravity. Specific gravity of 4.2 and above is ideally preferred and is rated as premium grade, though 4.1 $\mathrm{SG}$ is also acceptable [14]. Lower grade barite of 3.6-3.8 Specific gravity can also be used but will require a larger quantity of the mineral to weight up the mud as desired. Also a minimum amount of solids is desired in drilling mud formulation.

From Table 5, it was observed that sample $B_{1}$ was the heaviest with a specific gravity of 4.4 and sample $B_{2}$ with the lowest specific gravity of 4.0. An error of \pm 0.2 was considered in the measurements.

Table 5. Specific Gravity of Samples.

\begin{tabular}{lllllll}
\hline Sample & $\begin{array}{l}\text { Mass of measuring } \\
\text { cylinder }\end{array}$ & $\begin{array}{l}\text { Mass of cylinder }+ \\
\text { water }\end{array}$ & $\begin{array}{l}\text { Mass of barite } \\
+ \text { water }\end{array}$ & $\begin{array}{l}\text { Volume of } \\
\text { water }\end{array}$ & $\begin{array}{l}\text { Volume of barite }+ \\
\text { water }\end{array}$ & $\begin{array}{l}\text { Volume of } \\
\text { barite }\end{array}$ \\
\hline $\mathrm{B}_{0}$ & 84.65 & $106.45 \mathrm{~g}$ & $126.54 \mathrm{~g}$ & $20 \mathrm{ml}$ & $24.9 \mathrm{ml}$ \\
$\mathrm{B}_{1}$ & $84.6 \mathrm{~g}$ & $105.88 \mathrm{~g}$ & $125.85 \mathrm{~g}$ & $20 \mathrm{ml}$ & $24.5 \mathrm{ml}$ & 4.9 \\
$\mathrm{~B}_{2}$ & $84.66 \mathrm{~g}$ & $106.51 \mathrm{~g}$ & $125.56 \mathrm{~g}$ & $20 \mathrm{ml}$ & $25 \mathrm{ml}$ & $4.5 \mathrm{ml}$ \\
$\mathrm{B}_{3}$ & $81.69 \mathrm{~g}$ & 101.40 & $121.52 \mathrm{~g}$ & $20 \mathrm{ml}$ & $24.8 \mathrm{ml}$ & 5.4 \\
$\mathrm{~B}_{4}$ & $84.67 \mathrm{~g}$ & $106.67 \mathrm{~g}$ & $126.72 \mathrm{~g}$ & $20.5 \mathrm{ml}$ & $25.2 \mathrm{ml}$ & 4.0 \\
\hline
\end{tabular}

\section{Mud Weight}

The weight of the drilling mud determines the hydrostatic head in the well and therefore must be monitored and controlled always. In this study, the formulated drilling fluid samples were measured unweighted and then weighed after being weighted up by the addition of the 5 different sample of barites. $70 \mathrm{~g}$ of barite was added to each mud sample after formulation.

The results are as shown in Figures 3 to 5 .

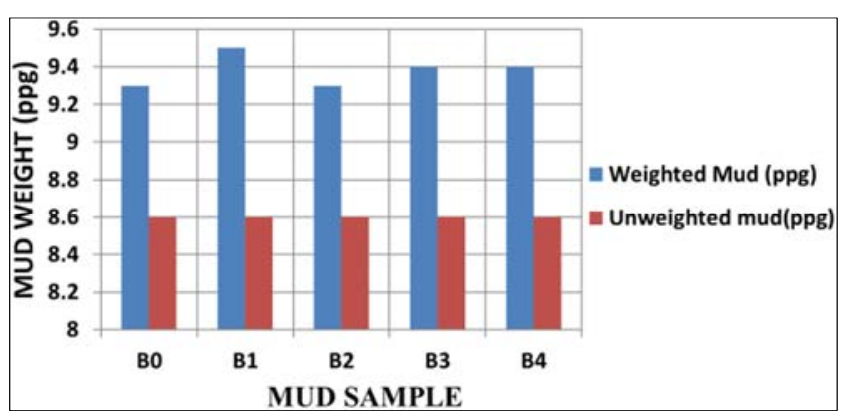

Figure 3. Mud weights of WBM.

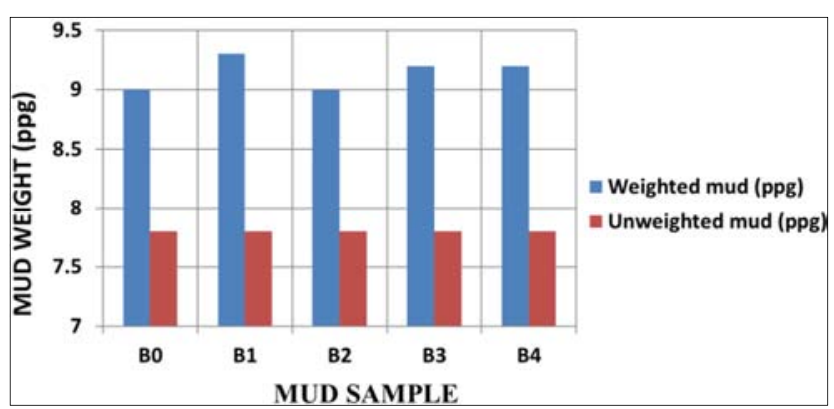

Figure 4. Mud weights of $O B M$.

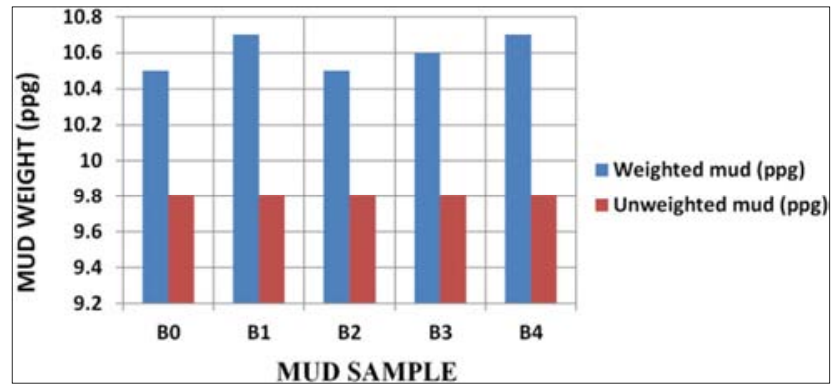

Figure 5. Mud weights of SBM. 
It can be clearly observed that sample $B_{1}$ had the most effect on the mud weight in all the drilling mud types. This is desired from a weighting additive as it will reduce the amount of solids in the drilling fluid while providing the desired mud weight.

Determination of Rheological Properties and Parameters

The viscometer readings of the drilling fluids are represented in Tables 6 to 17. The viscometer readings were used to calculate the fluid properties, such as the plastic viscosity, apparent viscosity and the yield points. These are shown in the rheograms (Figures 6 to 17).

The rheological properties were measured at increasing temperatures to observe the effect of temperature on the properties of the drilling fluid. The increasing temperatures can be said to be a simulation of well conditions while drilling.

Table 6. Properties of WBM at ambient conditions.

\begin{tabular}{|c|c|c|c|c|c|}
\hline & \multicolumn{5}{|l|}{ Readings } \\
\hline & $\mathbf{B}_{0}$ & $\mathbf{B}_{1}$ & $\mathbf{B}_{2}$ & $\mathbf{B}_{3}$ & $\mathbf{B}_{4}$ \\
\hline 10s Gel Strength $\left(\mathrm{lb} / 100 \mathrm{ft}^{2}\right)$ & 54 & 33 & 53 & 51 & 53 \\
\hline 10 mins Gel Strength $\left(\mathrm{lb} / 100 \mathrm{ft}^{2}\right)$ & 61 & 51 & 64 & 59 & 62 \\
\hline Apparent Viscosity (cp) & 32 & 25.5 & 32.5 & 31.5 & 31 \\
\hline Yield point $\left(\mathrm{lb} / 100 \mathrm{ft}^{2}\right)$ & 52 & 33 & 51 & 50 & 50 \\
\hline $\mathrm{n}$ & 0.0976 & 0.1763 & 0.1013 & 0.0800 & 0.0538 \\
\hline CCI & 97.74 & 41.47 & 93.80 & 104.34 & 120.54 \\
\hline CC@355gpm and 300ft/hr & \multicolumn{5}{|l|}{4.1537} \\
\hline Flow regime & \multicolumn{5}{|l|}{ Laminar } \\
\hline MAXROP & \multicolumn{5}{|c|}{ 364ft/hr@355gpm } \\
\hline
\end{tabular}

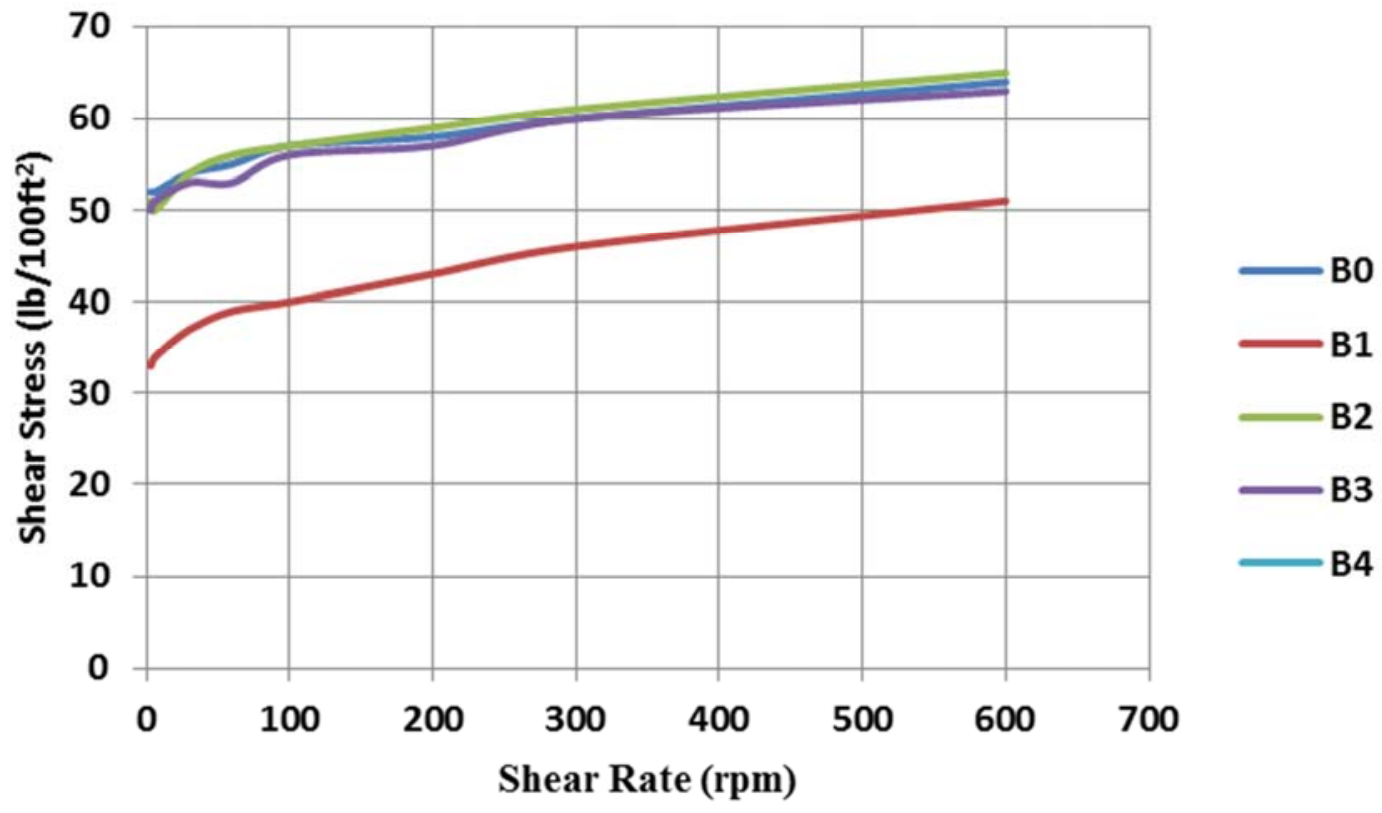

Figure 6. Rheogram of water based mud samples at ambient conditions.

Table 7. WBM at $120^{\circ} \mathrm{F}$.

\begin{tabular}{|c|c|c|c|c|c|}
\hline & \multicolumn{5}{|l|}{ Readings } \\
\hline & $\mathbf{B}_{\mathbf{0}}$ & $\mathbf{B}_{1}$ & $\mathbf{B}_{2}$ & $\mathbf{B}_{3}$ & $\mathbf{B}_{4}$ \\
\hline 10s Gel Strength $\left(\mathrm{lb} / 100 \mathrm{ft}^{2}\right)$ & 38 & 30 & 37 & 34 & 33 \\
\hline 10 mins Gel Strength $\left(\mathrm{lb} / 100 \mathrm{ft}^{2}\right)$ & 43 & 42 & 46 & 45 & 46 \\
\hline Plastic Viscosity (cp) & 3 & 2 & 3 & 4 & 4 \\
\hline Apparent Viscosity (cp) & 26 & 23 & 26 & 25 & 25.5 \\
\hline Yield point $\left(\mathrm{lb} / 100 \mathrm{ft}^{2}\right)$ & 38 & 30 & 35 & 33 & 34 \\
\hline $\mathrm{n}$ & 0.1019 & 0.0875 & 0.1096 & 0.1481 & 0.1444 \\
\hline CCI & 69.66 & 60.76 & 61.54 & 47.64 & 51.38 \\
\hline CC@355gpm and 300ft/hr & \multicolumn{5}{|l|}{4.1535} \\
\hline Flow regime & \multicolumn{5}{|l|}{ Laminar } \\
\hline MAXROP & \multicolumn{5}{|c|}{ 364ft/hr@355gpm } \\
\hline
\end{tabular}




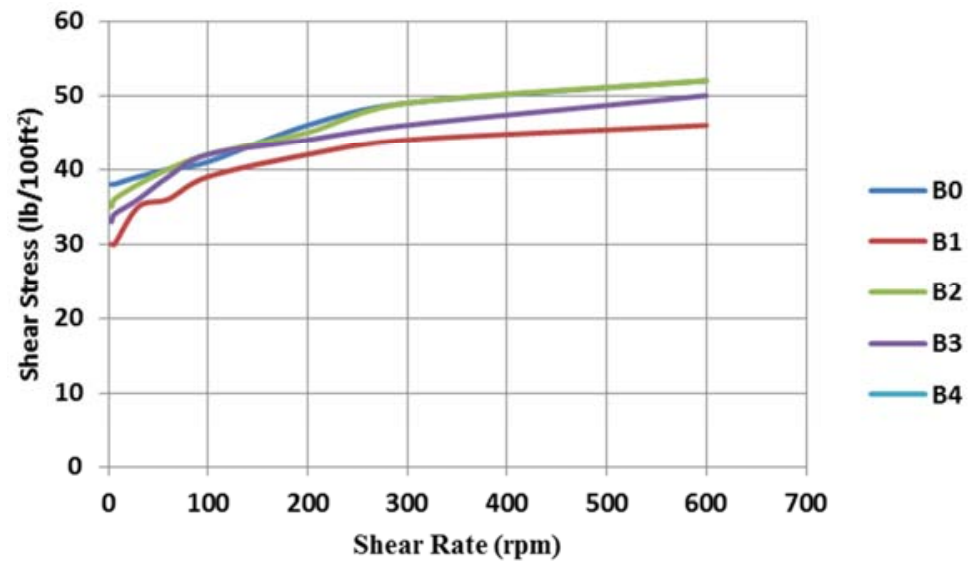

Figure 7. Rheogram of water based samples at $120^{\circ} \mathrm{F}$.

Table 8. WBM at $180^{\circ} \mathrm{F}$.

\begin{tabular}{llllll}
\hline & Readings & & & \\
\cline { 2 - 5 } & $\mathbf{B}_{\mathbf{0}}$ & $\mathbf{B}_{\mathbf{1}}$ & $\mathbf{B}_{\mathbf{2}}$ & $\mathbf{B}_{\mathbf{3}}$ & $\mathbf{B}_{\mathbf{4}}$ \\
\hline 10s Gel Strength $\left(\mathrm{lb} / 100 \mathrm{ft}^{2}\right)$ & 29 & 23 & 38 & 26 & 25 \\
10mins Gel Strength $\left(\mathrm{lb} / 100 \mathrm{ft}^{2}\right)$ & 38 & 31 & 46 & 34 & 33 \\
Plastic Viscosity $(\mathrm{cp})$ & 4 & 3 & 6 & 5 & 5 \\
Apparent Viscosity $(\mathrm{cp})$ & 23.5 & 21 & 24 & 22.5 & 22 \\
Yield point $\left(\mathrm{lb} / 100 \mathrm{ft}^{2}\right)$ & 28 & 24 & 27 & 26 & 25 \\
$\mathrm{n}$ & 0.17 & 0.15 & 0.24 & 0.22 & 0.22 \\
K & 5664.21 & 5414.04 & 3774.93 & 4017.26 & 3887.67 \\
CCI & 35.56 & 34.72 & 23.7 & 25.49 & 24.67 \\
CC@355gpm and 300ft/hr & 4.1537 & & & & \\
Flow regime & Laminar & & & & \\
MAXROP & $364 \mathrm{ft} / \mathrm{hr}$ (a) 355gpm & & & \\
\hline
\end{tabular}

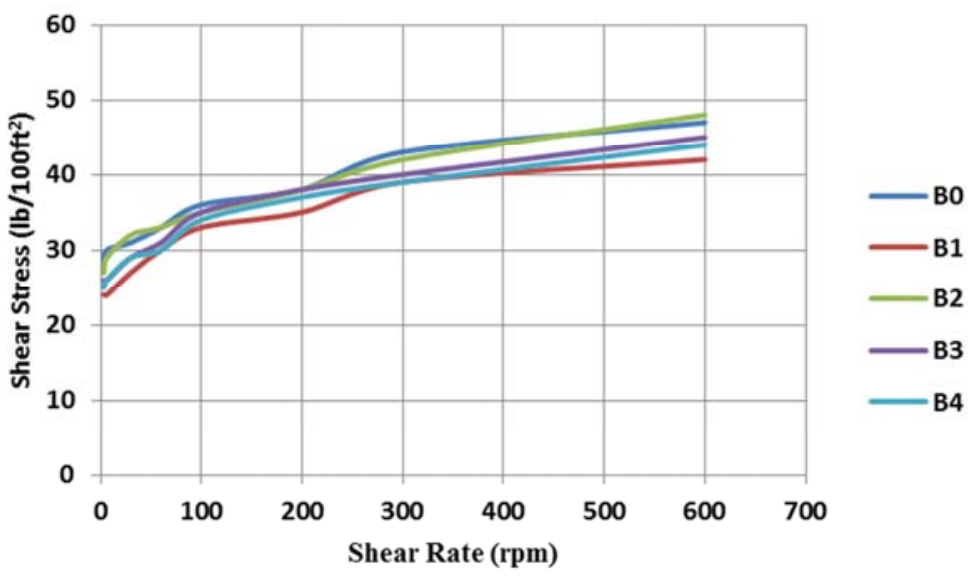

Figure 8. Rheogram of water based samples at $180^{\circ} \mathrm{F}$.

Table 9. WBM at $240^{\circ} \mathrm{F}$.

\begin{tabular}{|c|c|c|c|c|c|}
\hline & \multicolumn{5}{|c|}{ Readings } \\
\hline & $\mathbf{B}_{0}$ & $\mathbf{B}_{1}$ & $\mathbf{B}_{2}$ & $\mathbf{B}_{3}$ & $\mathbf{B}_{4}$ \\
\hline 10sGel Strength $\left(\mathrm{lb} / 100 \mathrm{ft}^{2}\right)$ & 21 & 20 & 22 & 21 & 20 \\
\hline 10mins Gel Strength $\left(\mathrm{lb} / 100 \mathrm{ft}^{2}\right)$ & 29 & 24 & 30 & 28 & 26 \\
\hline Plastic Viscosity (cp) & 4 & 4 & 3 & 4 & 4 \\
\hline Apparent Viscosity (cp) & 22 & 20.5 & 22 & 21 & 21 \\
\hline Yield point $\left(\mathrm{lb} / 100 \mathrm{ft}^{2}\right)$ & 23 & 22 & 24 & 23 & 22 \\
\hline $\mathrm{n}$ & 0.1993 & 0.2064 & 0.1519 & 0.1993 & 0.2064 \\
\hline $\mathrm{k}$ & 3981.04 & 3667.55 & 5350.27 & 3981.04 & 3667.55 \\
\hline CCI & 24.99 & 23.52 & 33.59 & 25.26 & 23.27 \\
\hline CC@355gpm and 300ft/hr & 4.1537 & & & & \\
\hline Flow regime & Laminar & & & & \\
\hline MAXROP & $364 \mathrm{ft} / \mathrm{hr}$ & & & & \\
\hline
\end{tabular}




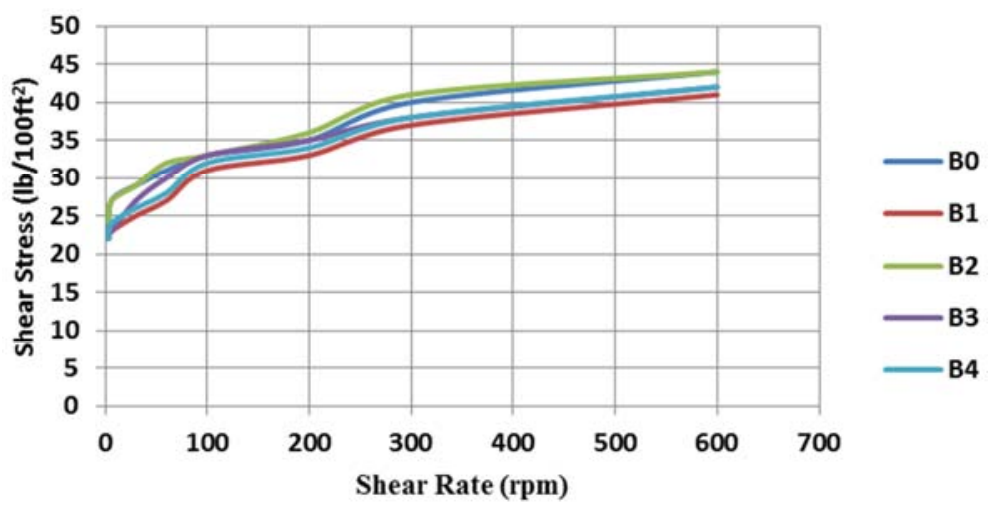

Figure 9. Rheogram of water based samples at $240^{\circ} \mathrm{F}$.

At ambient conditions, it was observed that mud sample $\mathrm{B}_{1}$ had a lower rheology when compared to the other mud samples. However as we go deeper and encounter hotter formations, the gap in rheology difference amongst all samples thins out although it remains the lowest rheology.
Sample $\mathrm{B}_{0}$ is seen to have a higher rheology and performs better than some other samples.

The results from the rheological tests of the Diesel Oil based mud samples are presented below;

Table 10. Properties of Diesel OBM at ambient condition

\begin{tabular}{|c|c|c|c|c|c|}
\hline & \multicolumn{5}{|c|}{ Readings } \\
\hline & $\mathbf{B}_{0}$ & $\mathbf{B}_{1}$ & $\mathbf{B}_{2}$ & $\mathbf{B}_{3}$ & $\mathbf{B}_{4}$ \\
\hline 10s Gel (lb/100ft $\left.{ }^{2}\right)$ & 27 & 24 & 24 & 25 & 25 \\
\hline 10mins Gel Strength $\left(\mathrm{lb} / 100 \mathrm{ft}^{2}\right)$ & 39 & 33 & 40 & 35 & 34 \\
\hline Plastic Viscosity (cp) & 42 & 41 & 42 & 41 & 41 \\
\hline Apparent Viscosity (cp) & 77.5 & 75.5 & 79 & 76.5 & 76 \\
\hline Yield point $\left(\mathrm{lb} / 100 \mathrm{ft}^{2}\right)$ & 26 & 23 & 25 & 24 & 23 \\
\hline $\mathrm{n}$ & 0.6939 & 0.7142 & 0.7021 & 0.7056 & 0.7142 \\
\hline $\mathrm{k}$ & 654.54 & 380.41 & 429.45 & 407.64 & 380.41 \\
\hline $\mathrm{CCI}$ & 3.98 & 2.39 & 2.61 & 2.53 & 2.36 \\
\hline CC@355gpm and 300ft/hr & \multicolumn{5}{|l|}{4.1538} \\
\hline Flow regime & \multicolumn{5}{|c|}{ Laminar } \\
\hline MAXROP & \multicolumn{5}{|c|}{ 364ft/hr@355gpm } \\
\hline
\end{tabular}

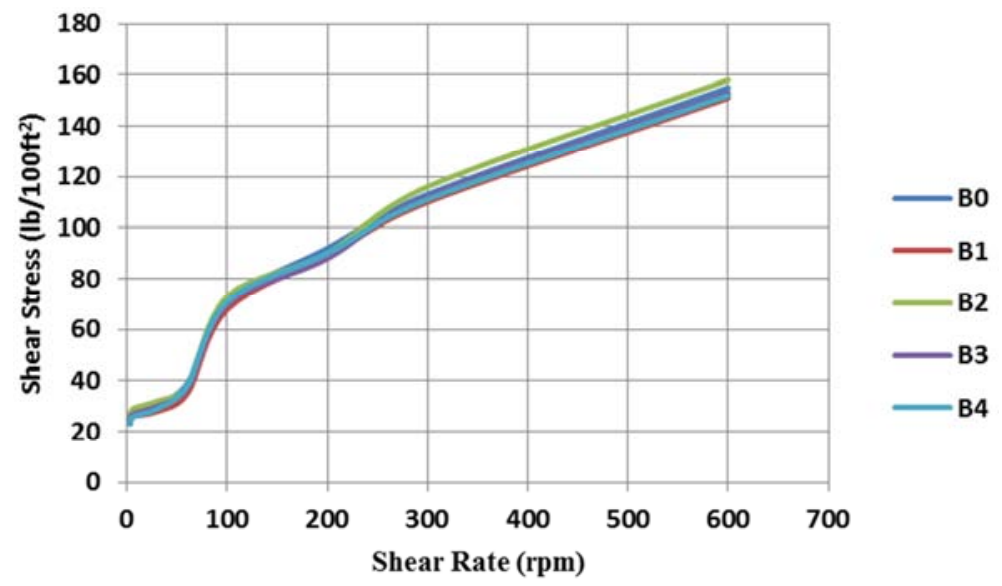

Figure 10. Rheogram of Diesel OBM at ambient condition.

Table 11. Diesel $\mathrm{OBM}$ at $120^{\circ} \mathrm{F}$.

\begin{tabular}{llllll}
\hline & Readings & & & \\
\cline { 2 - 6 } & $\mathbf{B}_{\mathbf{0}}$ & $\mathbf{B}_{\mathbf{1}}$ & $\mathbf{B}_{\mathbf{2}}$ & $\mathbf{B}_{\mathbf{3}}$ & $\mathbf{B}_{\mathbf{4}}$ \\
\hline 10s Gel Strength $\left(\mathrm{lb} / 100 \mathrm{ft}^{2}\right)$ & 25 & 22 & 25 & 21 & 22 \\
10mins Gel Strength $\left(\mathrm{lb} / 100 \mathrm{ft}^{2}\right)$ & 38 & 30 & 40 & 32 & 34 \\
Plastic Viscosity $(\mathrm{cp})$ & 40 & 39 & 40 & 36 & 42 \\
Apparent Viscosity $(\mathrm{cp})$ & 75 & 20 & 76 & 72 & 72.5 \\
Yield point $\left(\mathrm{lb} / 100 \mathrm{ft}^{2}\right)$ & 22 & 0.7321 & 23 & 22 & 21 \\
$\mathrm{n}$ & 0.7183 & & 0.7092 & 0.6966 & 0.7364 \\
\hline
\end{tabular}




\begin{tabular}{llllll}
\hline & \multicolumn{2}{l}{ Readings } & & & $\mathbf{B}_{\mathbf{3}}$ \\
\cline { 2 - 5 } & $\mathbf{B}_{\mathbf{0}}$ & $\mathbf{B}_{\mathbf{1}}$ & $\mathbf{B}_{\mathbf{2}}$ & $\mathbf{B}_{\mathbf{4}}$ \\
\hline $\mathrm{k}$ & 359.21 & 313.64 & 386.32 & 384.74 & 2.39 \\
$\mathrm{CCI}$ & 2.18 & 1.97 & 2.35 & 2.02 \\
CC@355gpm and 300ft/hr & 4.1539 & & & \\
Flow regime & Laminar & & & \\
MAXROP & 364ft/hr@355gpm & & & \\
\hline
\end{tabular}

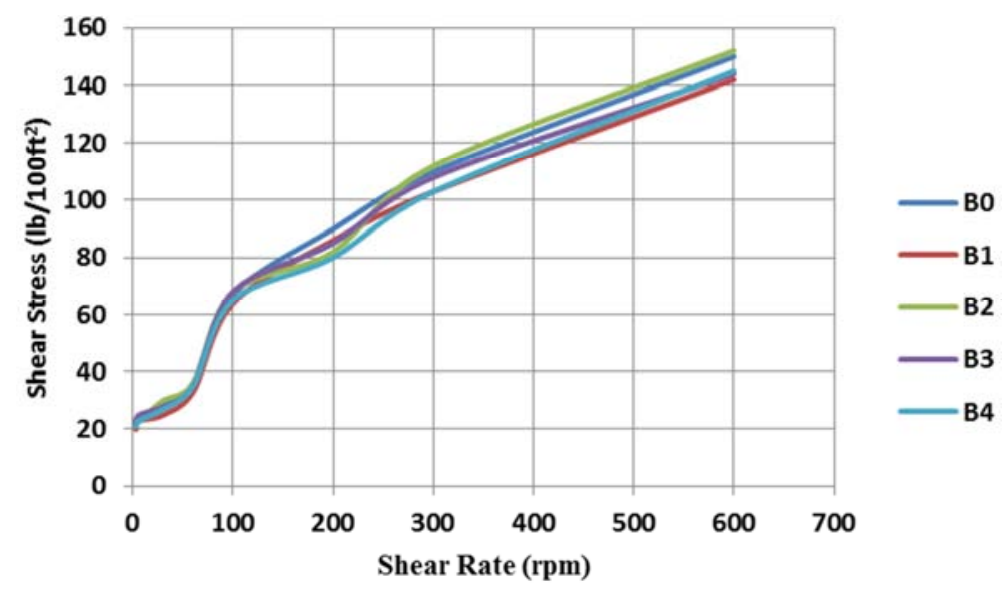

Figure 11. Rheogram of Diesel $O B M$ at $120^{\circ} \mathrm{F}$.

Table 12. Diesel $O B M$ at $180^{\circ} \mathrm{F}$.

\begin{tabular}{|c|c|c|c|c|c|}
\hline & \multicolumn{5}{|c|}{ Readings } \\
\hline & $\mathbf{B}_{0}$ & $\mathbf{B}_{1}$ & $\mathbf{B}_{2}$ & $\mathbf{B}_{3}$ & $\mathbf{B}_{4}$ \\
\hline 10s Gel Strength $\left(\mathrm{lb} / 100 \mathrm{ft}^{2}\right)$ & 20 & 18 & 21 & 19 & 19 \\
\hline 10 mins Gel Strength $\left(\mathrm{lb} / 100 \mathrm{ft}^{2}\right)$ & 36 & 29 & 35 & 30 & 28 \\
\hline Plastic Viscosity (cp) & 42 & 45 & 35 & 41 & 38 \\
\hline Apparent Viscosity (cp) & 71.5 & 65.5 & 70 & 67.5 & 66.5 \\
\hline Yield point $\left(\mathrm{lb} / 100 \mathrm{ft}^{2}\right)$ & 18 & 16 & 20 & 18 & 18 \\
\hline $\mathrm{n}$ & 0.7656 & 0.7991 & 0.7105 & 0.7612 & 0.7473 \\
\hline $\mathrm{k}$ & 251.82 & 212.33 & 335.59 & 263.56 & 263.56 \\
\hline $\mathrm{CCI}$ & 1.53 & 1.33 & 2.04 & 1.64 & 1.65 \\
\hline CC@355gpm and 300ft/hr & \multicolumn{5}{|l|}{4.1540} \\
\hline Flow regime & \multicolumn{5}{|l|}{ Laminar } \\
\hline MAXROP & \multicolumn{5}{|c|}{ 364ft/hr@355gpm } \\
\hline
\end{tabular}

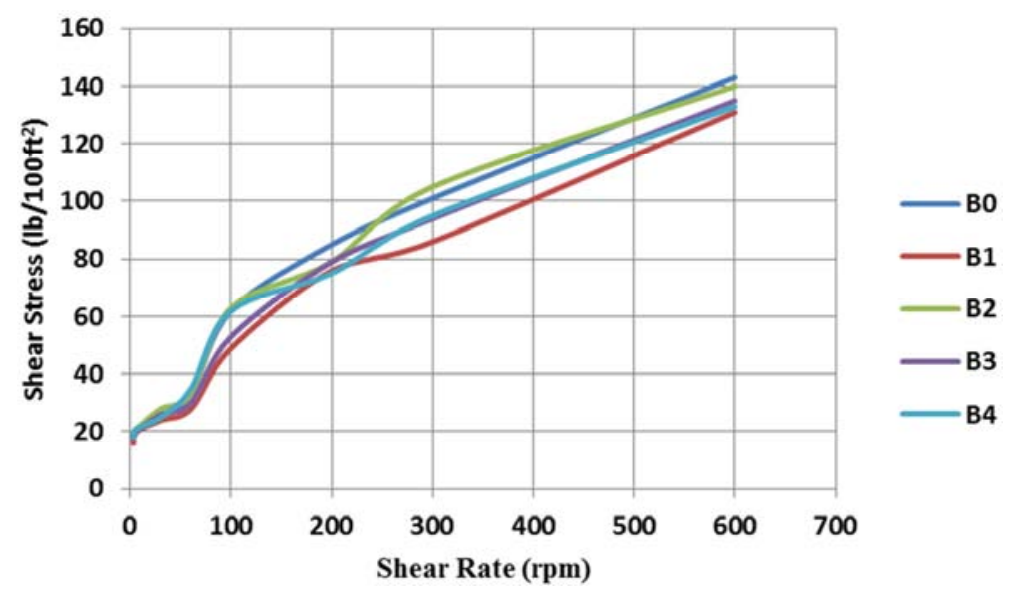

Figure 12. Rheogram of Diesel $O B M$ at $180^{\circ} \mathrm{F}$.

Table 13. Diesel $O B M$ at $240^{\circ} \mathrm{F}$.

\begin{tabular}{llllll}
\hline & Readings & & & \\
\cline { 2 - 6 } & $\mathbf{B}_{\mathbf{0}}$ & $\mathbf{B}_{\mathbf{1}}$ & $\mathbf{B}_{\mathbf{2}}$ & $\mathbf{B}_{\mathbf{3}}$ & $\mathbf{B}_{\mathbf{4}}$ \\
\hline 10s Gel Strength $\left(\mathrm{lb} / 100 \mathrm{ft}^{2}\right)$ & 15 & 13 & 16 & 18 & 15 \\
10mins Gel Strength $\left(\mathrm{lb} / 100 \mathrm{ft}^{2}\right)$ & 31 & 27 & 32 & 28 & 28 \\
\hline
\end{tabular}




\begin{tabular}{llllll}
\hline & Readings & & & \\
\cline { 2 - 5 } & $\mathbf{B}_{\mathbf{0}}$ & $\mathbf{B}_{\mathbf{1}}$ & $\mathbf{B}_{\mathbf{2}}$ & $\mathbf{B}_{\mathbf{3}}$ & $\mathbf{B}_{\mathbf{4}}$ \\
\hline Plastic Viscosity (cp) & 44 & 43 & 37 & 39 & 41 \\
Apparent Viscosity (cp) & 69.5 & 62 & 67.5 & 64 & 65 \\
Yield point (lb/100ft $\left.{ }^{2}\right)$ & 13 & 11 & 15 & 13 & 16 \\
$\mathrm{n}$ & 0.8253 & 0.8450 & 0.7749 & 0.8074 & 0.7818 \\
$\mathrm{k}$ & 169.45 & 141.97 & 211.67 & 172.84 & 222.26 \\
CCI & 1.03 & 0.89 & 1.29 & 1.07 & \\
CC@355gpm and 300ft/hr & 4.1542 & & & & \\
Flow regime & Laminar & $364 \mathrm{ft} / \mathrm{hr} @ 355 \mathrm{gpm}$ & & & \\
MAXROP & & & & \\
\hline
\end{tabular}

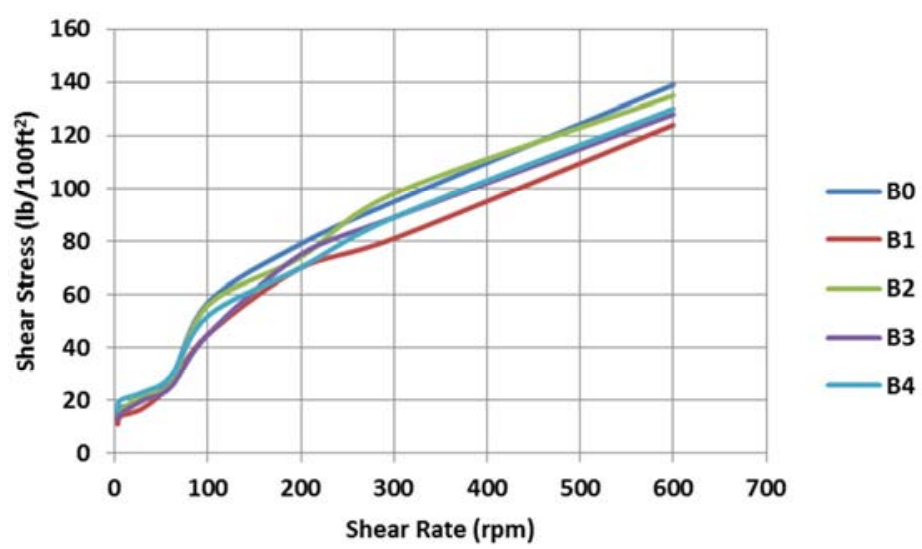

Figure 13. Rheogram of Diesel OBM at $240^{\circ} \mathrm{F}$.

Generally, the results from the sample drilling muds were close to each other but as the temperature increases, their performance became a little altered. They followed the same rheological model throughout and thus can be substitutes for each other. Sample $B_{1}$ is seen to also have the lowest rheology.

The results from the rheological tests of the synthetic fluid samples are as follows.

Table 14. Properties of SBM at ambient conditions.

\begin{tabular}{|c|c|c|c|c|c|}
\hline & \multicolumn{5}{|l|}{ Readings } \\
\hline & $\mathbf{B}_{\mathbf{0}}$ & $\mathbf{B}_{1}$ & $\mathbf{B}_{2}$ & $\mathbf{B}_{3}$ & $\mathbf{B}_{4}$ \\
\hline 10s Gel Strength $\left(\mathrm{lb} / 100 \mathrm{ft}^{2}\right)$ & 9 & 8 & 14 & 12 & 11 \\
\hline 10 mins Gel Strength $\left(\mathrm{lb} / 100 \mathrm{ft}^{2}\right)$ & 21 & 17 & 23 & 19 & 20 \\
\hline Plastic Viscosity (cp) & 37 & 33 & 37 & 37 & 35 \\
\hline Apparent Viscosity (cp) & 51 & 45 & 52.5 & 50.5 & 51.5 \\
\hline Yield point $\left(\mathrm{lb} / 100 \mathrm{ft}^{2}\right)$ & 10 & 7 & 12 & 11 & 10 \\
\hline $\mathrm{n}$ & 0.8377 & 0.8679 & 0.8114 & 0.8244 & 0.8295 \\
\hline $\mathrm{CCI}$ & 0.92 & 0.66 & 1.13 & 1.03 & 0.92 \\
\hline CC@355gpm and 300ft/hr & 4.1541 & & & & \\
\hline Flow regime & Laminar & & & & \\
\hline MAXROP & 364ft/hr@355gpm & & & & \\
\hline
\end{tabular}

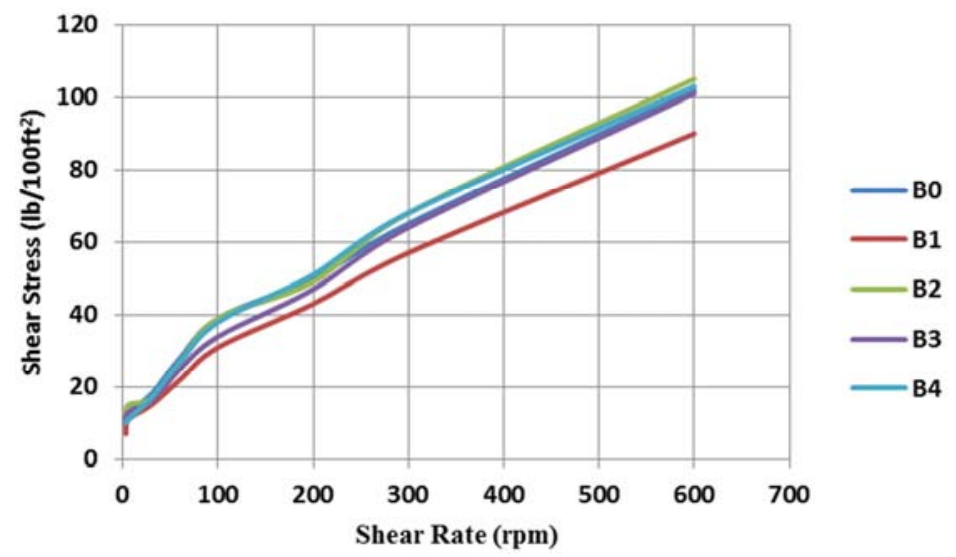

Figure 14. Rheogram of SBM at Ambient conditions. 
Table 15. SBM at $120^{\circ} \mathrm{F}$.

\begin{tabular}{|c|c|c|c|c|c|}
\hline & \multicolumn{5}{|c|}{ Readings } \\
\hline & $\mathbf{B}_{0}$ & $\mathbf{B}_{1}$ & $\mathbf{B}_{2}$ & $\mathbf{B}_{3}$ & $\mathbf{B}_{4}$ \\
\hline 10s Gel Strength $\left(\mathrm{lb} / 100 \mathrm{ft}^{2}\right)$ & 10 & 9 & 14 & 11 & 10 \\
\hline 10 mins Gel Strength $\left(\mathrm{lb} / 100 \mathrm{ft}^{2}\right)$ & 21 & 18 & 21 & 19 & 18 \\
\hline Plastic Viscosity (cp) & 37 & 34 & 38 & 36 & 37 \\
\hline Apparent Viscosity (cp) & 49.5 & 44 & 52 & 49 & 49.5 \\
\hline Yield point $\left(\mathrm{lb} / 100 \mathrm{ft}^{2}\right)$ & 10 & 7 & 10 & 9 & 9 \\
\hline $\mathrm{n}$ & 0.8377 & 0.8713 & 0.8413 & 0.8480 & 0.8515 \\
\hline $\mathrm{k}$ & 129.32 & 91.49 & 129.14 & 116.12 & 116.13 \\
\hline CCI & 0.92 & 0.66 & 0.92 & 0.83 & 0.82 \\
\hline $\mathrm{CC} @ 355 \mathrm{gpm}$ and $300 \mathrm{ft} / \mathrm{hr}$ & \multicolumn{5}{|l|}{4.1541} \\
\hline Flow regime & \multicolumn{5}{|l|}{ Laminar } \\
\hline MAXROP & \multicolumn{5}{|c|}{ 364ft/hr@355gpm } \\
\hline
\end{tabular}

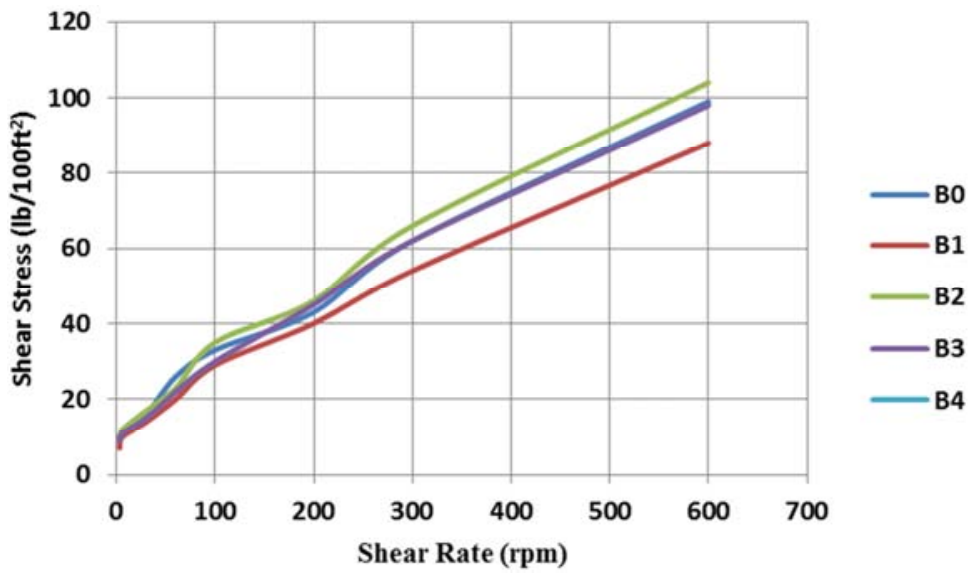

Figure 15. Rheogram of SBM at $120^{\circ} \mathrm{F}$.

Table 16. SBM at $180^{\circ} \mathrm{F}$.

\begin{tabular}{|c|c|c|c|c|c|}
\hline & \multicolumn{5}{|l|}{ Readings } \\
\hline & $\mathbf{B}_{0}$ & $\mathbf{B}_{1}$ & $\mathbf{B}_{2}$ & $\mathbf{B}_{3}$ & $\mathbf{B}_{4}$ \\
\hline 10s Gel Strength $\left(\mathrm{lb} / 100 \mathrm{ft}^{2}\right)$ & 7 & 6 & 8 & 6 & 7 \\
\hline 10mins Gel Strength $\left(\mathrm{lb} / 100 \mathrm{ft}^{2}\right)$ & 14 & 13 & 18 & 15 & 14 \\
\hline Plastic Viscosity (cp) & 38 & 35 & 37 & 37 & 38 \\
\hline Apparent Viscosity (cp) & 49 & 42.5 & 49.5 & 47.5 & 48.5 \\
\hline Yield point $\left(\mathrm{lb} / 100 \mathrm{ft}^{2}\right)$ & 7 & 5 & 8 & 6 & 7 \\
\hline $\mathrm{n}$ & 0.8829 & 0.9069 & 0.8655 & 0.8953 & 0.8829 \\
\hline $\mathrm{k}$ & 95.11 & 74.63 & 101.23 & 80.23 & 95.11 \\
\hline $\mathrm{CCI}$ & 0.67 & 0.54 & 0.72 & 0.57 & 0.69 \\
\hline CC@355gpm and 300ft/hr & 4.1542 & & & & \\
\hline Flow regime & Laminar & & & & \\
\hline MAXROP & 364ft/hr@355gpm & & & & \\
\hline
\end{tabular}

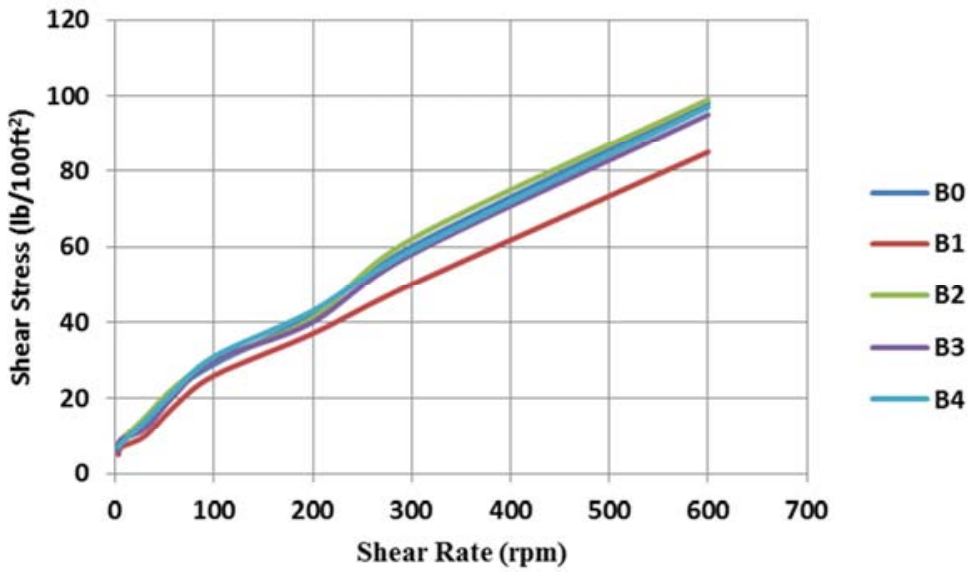

Figure 16. Rheogram of $S B M$ at $180^{\circ} \mathrm{F}$. 
Table 17. SBM at $240^{\circ} \mathrm{F}$.

\begin{tabular}{|c|c|c|c|c|c|}
\hline & \multicolumn{5}{|c|}{ Readings } \\
\hline & $\mathbf{B}_{0}$ & $\mathbf{B}_{1}$ & $\mathbf{B}_{2}$ & $\mathbf{B}_{3}$ & $\mathbf{B}_{4}$ \\
\hline 10s Gel Strength $\left(\mathrm{lb} / 100 \mathrm{ft}^{2}\right)$ & 7 & 5 & 7 & 8 & 7 \\
\hline 10mins Gel Strength $\left(\mathrm{lb} / 100 \mathrm{ft}^{2}\right)$ & 13 & 11 & 14 & 15 & 13 \\
\hline Plastic Viscosity (cp) & 38 & 34 & 35 & 36 & 39 \\
\hline Apparent Viscosity (cp) & 47.5 & 39.5 & 48 & 47 & 47.5 \\
\hline Yield point $\left(\mathrm{lb} / 100 \mathrm{ft}^{2}\right)$ & 7 & 4 & 7 & 6 & 5 \\
\hline $\mathrm{n}$ & 0.8829 & 0.9220 & 0.8745 & 0.8931 & 0.9157 \\
\hline $\mathrm{k}$ & 93.40 & 61.81 & 91.87 & 81.80 & 74.43 \\
\hline $\mathrm{CCI}$ & 0.66 & 0.45 & 0.65 & 0.59 & 0.54 \\
\hline CC@355gpm and 300ft/hr & \multicolumn{5}{|l|}{4.1542} \\
\hline Flow regime & \multicolumn{5}{|l|}{ Laminar } \\
\hline MAXROP & \multicolumn{5}{|c|}{$364 \mathrm{ft} / \mathrm{hr} @ 355 \mathrm{gpm}$} \\
\hline
\end{tabular}

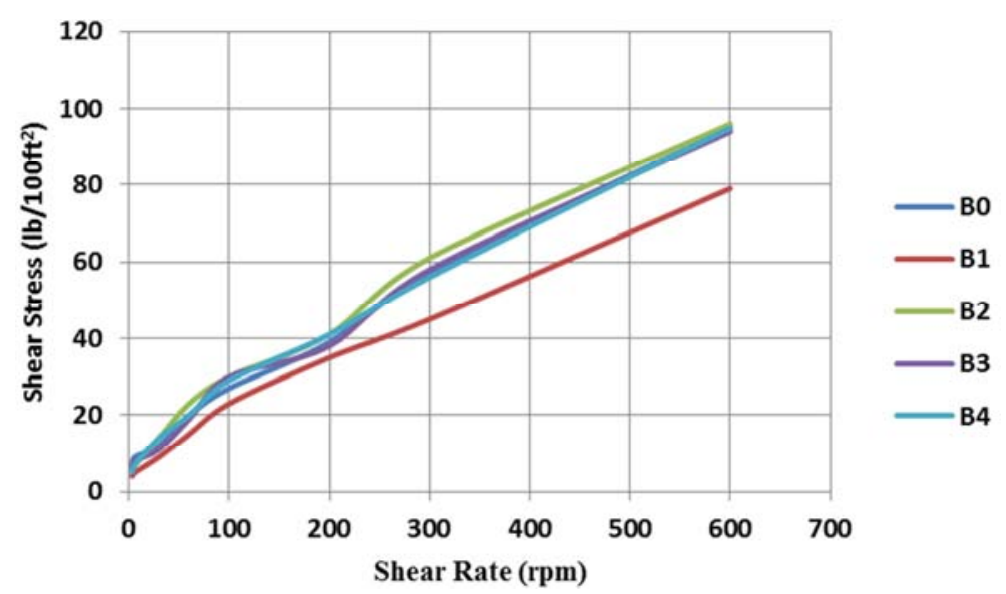

Figure 17. Rheogram of $S B M$ at $240^{\circ} \mathrm{F}$.

Fluid Loss Tests

The fluid loss tests were carried out in HP-HT conditions. The fluid losses and filter cake thicknesses were measured after 30 minutes and presented in Tables 18 to 20 . It was observed that samples $\mathrm{B}_{1}$ to $\mathrm{B}_{4}$ have comparable fluid losses and filter cake thicknesses for all the drilling mud types.

Table 18. Water based mud.

\begin{tabular}{llllll}
\hline Sample & $\boldsymbol{B}_{\boldsymbol{0}}$ & $\boldsymbol{B}_{\boldsymbol{1}}$ & $\boldsymbol{B}_{\mathbf{2}}$ & $\boldsymbol{B}_{3}$ & $\boldsymbol{B}_{4}$ \\
\hline Fluid loss volume & $27 \mathrm{ml}$ & $29 \mathrm{ml}$ & $25 \mathrm{ml}$ & $26 \mathrm{ml}$ & $27 \mathrm{ml}$ \\
Filter Cake & $2 \mathrm{~mm}$ & $2 \mathrm{~mm}$ & $2 \mathrm{~mm}$ & $2 \mathrm{~mm}$ & $2 \mathrm{~mm}$ \\
\hline
\end{tabular}

Table 19. Diesel OBM.

\begin{tabular}{llllll}
\hline Sample & $\boldsymbol{B}_{\boldsymbol{0}}$ & $\boldsymbol{B}_{\boldsymbol{1}}$ & $\boldsymbol{B}_{2}$ & $\boldsymbol{B}_{3}$ & $\boldsymbol{B}_{4}$ \\
\hline Fluid loss volume & $17 \mathrm{ml}$ & $15 \mathrm{ml}$ & $17 \mathrm{ml}$ & $17 \mathrm{ml}$ & $19 \mathrm{ml}$ \\
Filter Cake thickness & $2 \mathrm{~mm}$ & $2 \mathrm{~mm}$ & $2 \mathrm{~mm}$ & $2 \mathrm{~mm}$ & $2 \mathrm{~mm}$ \\
\hline
\end{tabular}

Table 20. Synthetic Based Mud.

\begin{tabular}{llllll}
\hline Sample & $\boldsymbol{B}_{0}$ & $\boldsymbol{B}_{1}$ & $\boldsymbol{B}_{2}$ & $\boldsymbol{B}_{3}$ & $\boldsymbol{B}_{4}$ \\
\hline Fluid loss volume & $12 \mathrm{ml}$ & $13 \mathrm{ml}$ & $12 \mathrm{ml}$ & $13 \mathrm{ml}$ & $13 \mathrm{ml}$ \\
Filter Cake & $3 \mathrm{~mm}$ & $4 \mathrm{~mm}$ & $4 \mathrm{~mm}$ & $4 \mathrm{~mm}$ & $3 \mathrm{~mm}$ \\
\hline
\end{tabular}

\section{Conclusion and Recommendations}

\subsection{Conclusion}

Generally the mud weights of the various barite weighted samples in the OBM, WBM and SBM were relatively close. It was clearly seen that barite sample $B_{1}$, having the highest specific gravity always had the highest mud weight in every type of drilling mud. A lower 4.10 SG barite is also acceptable [14]. This also reflected in the rheological properties as its plastic viscosity and gel strength came out more favourable. It was observed that there was a reduction in the mud weight and viscosities as the temperature was increased. With these results when compared with the API Barite $\left(\mathrm{B}_{0}\right)$, it can be seen that Nigerian barites perform favourably as weighting materials, even in high temperatures and can reduce dependence on expensive alternatives [13]. It was observed that samples $\mathrm{B}_{1}$ to $\mathrm{B}_{4}$ have comparable fluid losses and filter cake thicknesses for all the mud types.

The barites used for this experiment are readily available in commercial quantities but in its unprocessed form, thus some errors and problems encountered may be as a result of its crude and unprocessed state. Pristine processing techniques and equipment should be used to achieve industrial premium grade finished products. This will make it easy to use and would improve the export value.

\subsection{Recommendations}

i. From the experience of other barite mines, it was discovered that as the veins are being exploited, the quality of the mineral reduces, i.e the specific gravity may reduce as the vein is being depleted. Due to continuous mining and increase in the demand for barite, there is a possibility of the world lacking enough quantities of High grade Premium barite of 4.2 
SG [14]. In that light, a beneficiation process would be recommended, to yield more quantities. The process may involve mixing low grade barite and high grade barite at a pre-determined proportion to achieve the approved standard.

ii. Barite should be micronized to have a maximum particle size of at least $3 \%<45 \mu \mathrm{m}$. An average particle size of $1 \mu \mathrm{m}$ is preferable. Adequate machinery should be provided for this measure to be achieved. Impurities like Quartz and Silicon (IV) Oxide should be reduced to as low as reasonably possible.

iii. The Nigerian government should issue import wavers on barite processing equipment and tax holidays to individuals or companies that choose to venture into processing of local barites to encourage the growth of the industry in Nigeria.

iv. Although Irvingia gabonesis is relatively expensive and is categorised as edible vegetable plant, extracting its oil for industrial use will be an economical challenge but its results is worth it. However, plantations can be set up strictly for production of industrial use of Irvingia gabonesis. More research can be carried out on its usability for oil in water emulsion; this will reduce the amount of oil being used and reduce cost also. Irvingia gabonesis is environmentally friendly, biodegradable and requires very low disposal cost. Due to certain setbacks in this research such as time restrictions and financial demands, experiments to ensure the usability of Irvingia gabonesis oil was impaired. Further research would be required to discover the appropriate bridging agent or emulsifying agent required to create a homogenous fluid.

v. There are organic biodegradable synthetic based fluids that are being used in the industry, sadly an attempt to use Irvingia gabonesis oil as a substitute base fluid in this study did not work out. More research is required to make this a success.

\section{References}

[1] Oyeneyin, M. B. (2004). Lecture notes on drilling fluids technology, Shell Special Intensive Training Programme.

[2] Izuwa, N. C. (2015). Evaluating the impact of rheological property of local viscosifier on hole cleaning. FUTO Journal Series (FUTOJNLS), Vol. 1, Issue 1.

[3] Omotioma, M. Ejikeme, P. C. N and Ume, J. I (2015). Improving the rheological properties of water based mud with the addition of cassava starch. International Journal of Environmental Science, Management and Engineering Research. Vol. 8, Issue 8 pp. 70-73.
[4] Uwaezuoke, N., Igwilo, K. C., Onwukwe, S. I and Obah, B. (2017). Effects of temperature on Mucuna solannie waterbased mud properties. International Journal of Advanced Engineering Research and Science, 4 (1): 83-92p.

[5] Uwaezuoke, N., Igwilo, K. C., Onwukwe, S. I and Obah, B. (2017). Optimization of Mucuna solannie mud rheological parameters. Journal of Petroleum Engineering and Technology, 7 (1): 15-26 p.

[6] Zamora, M. and Bell, R. (2004). Improved well-site test for monitoring barite sag. American Association of Drilling Engineers Conference, Houston. AADE-04-DFHO-19.

[7] Svendsen, Ø., Toften, J. K., Marshall, D. S. et al. (1995). Use of a novel drill-In/completion fluid based on Potassium formate brine on the first open-hole completion in the Gullfaks Field. SPE-29409 http://dx.doi.org/10.2118/29409-MS.

[8] Haaland, Ellen, Pettersengier, and Tuntland (1976). Testing of Iron oxide as weight material for drilling fluid'. Journal of Petroleum Engineering, 6280-MS.

[9] Onu, O. V., and Ikponmwosa, O. (2014). Antimony Sulphide (Stibnite) and Potash as local substitute to barite and lignosulfonate as drilling mud weighting additives. SPE: doi: 10.2118/172407-MS.

[10] Bloomberg, N. E., and Melberg, B. (1984). Evaluation of ilmenite as weight material in drilling fluids society of petroleum engineers. doi: 10.2118/11085-PA.

[11] Nigerian Geological Survey Agency under the Ministry of Mines and Steel Development (2010). Barytes: Exploration Opportunities in Nigeria.

[12] Emmanuel, E. (2015). Exploration and production of barite in Cross River to meet growing demand by international oil companies. Cross River Watch. Available from: http://crossriverwatch.com/2015/08/exploration-andproduction-of-barite-in-cross-river-to-meet-growing-demandby-international-oil-companies-by-emmanuel-etim/.

[13] Al-bagoury M. and Steele, C. D. (2012). A new, alternative weight material for drilling fluids. Society of Petroleum Engineers. doi: 10.2118/151331-MS.

[14] Bruton, J. R., Bacho, J. P., and Newcaster, J. (2006). The future of drilling-grade barite weight material - a case for a substitute specification. Society of Petroleum Engineers. doi: 10.2118/103135-MS

[15] API Recommended Practice 13B (2005). API Recommended Practice for field testing drilling fluids (5thedition). Washington: API, Vol. 13 B, pp. 9-10.

[16] Ofesi, S. F., Onwukwe, S. I., and Duru, U. I. (2017). Optimizing hole cleaning using low viscosity drilling fluid. Advances in Petroleum Exploration and Development, 14 (1), 55-61. 